\title{
Pääkirjoitus
}

\section{Kirjasto merkitsee jatkuvuutta, vapautta ja rauhaa}

Hyvä lukija, luet Signumin Suomi 100 -juhlanumeroa. Lehti perustuu tällä kertaa Suomen tieteellisen kirjastoseuran Suomi 100 -juhlaseminaarissa Tieto, avoimuus ja kirjastot - jatkunko menestystarina? pidettyihin puheenvuoroihin 23.11.2017 Tieteiden talolla. Lisäksi lukupaketista löytyy journalistisen kirjoittamisen dosentin Maria LassilaMerisalon ajankohtainen artikkeli, joka pohjautuu hänen pitämäänsä keynote-puheenvuoroon Informaatiolukutaito-työryhmän seminaarissa Tiedon monet kasvot - mikä on oikeaa tietoa, kuka valitsee faktat.

Seminaarissa esitettiin kirjaston rakastajien puheenvuoroja videolla. Videotervehdyksissä esiintyivät Helsingin yliopiston eurooppaoikeuden professori Juha Raitio, opiskelija Annukka Saaristo Helsingin yliopiston humanistisesta tiedekunnasta ja Eduskunnan puhemiehen erityisavustaja Timo Turja.

- Kirjasto merkitsee vapautta, sitä, että saan etsiä haluamaani tietoa, kertoo Annukka Saaristo. - Toisaalta kirjastosta löytää myös sellaista, mitä ei osaa etsiä.

- Kirjastosta löytyy koko maailma, hän toteaa. Laman lapselle kirjasto tarjosi paikkoja, joihin ei muuten olisi ollut mahdollisuutta päästä.

Jos Annukka Saaristo saisi taikasauvan, jokaisen ulottuvilla olisi erinomainen kirjasto ja aikuiset veisivät lapsia pienestä pitäen kirjastoihin, sillä kirjasto edistää yksilön kielen oppimista sekä laajemmin suomen kielen säilymistä ja kehittämistä.

Kun työasia on saatava nopeasti tehtyä, professori Juha Raitio pakenee pirisevää puhelintaan ja sähköpostitulvaa hetkeksi työhuoneestaan viereiseen Kaisa-talon kirjastoon.

- Kirjasto on paikka, jossa pystyy keskittymään. Keskittymisen tarvetta ei voi opiskelussakaan sivuuttaa. Joskus pitää olla rauhassa yksin ja hiljaa, lukea ja yrittää ymmärtää. Meille juristeille kirjasto on äärimmäisen tärkeä paikka.”

Timo Turja näkee kirjastojen pitkän historian suurena voimavarana.

- Toivon, että kirjastoväki pitää huolta historiallisesta ymmärryksestään, muististaan. Minuun on tehnyt suuren vaikutuksen vanhat maalaukset kirjastoista: löytyy puupiirroksia 1400-luvun luostarikirjastoista ja maalauksia renessanssikirjastoista. Maalausten kirjastot ovat hyvin samankaltaisia kuin nykypäivänä: ihmisiä lukemassa, kirjoja luet- 
tavana, pöytä, jonka äärellä luetaan. Kirjaston olemuksessa, töissä ja tehtävissä on ollut suurta jatkuvuutta.

Turja uskoo, että kirjastojen tulevaisuutta määrittelee enemmän tämä jatkuvuus kuin muutos. Vaikka yhteiskunta ja teknologia muuttuvat, kirjaston arvot ja käyttäjien tarpeet eivät muutu. Kirjastojen työntekijöiden tulee pitää huolta tiedonvälitysinstituutioistaan.

STKS:n puheenjohtaja Jarmo Saarti seminaarissa totesi, että kirjastot ovat rakentaneet suomalaista, vapaata ja itsenäistä yhteiskuntaa. Olemme osaltamme luoneet sivistystä ja valoa, kuten Laura Kolbe kuvailee rooliamme haastattelussaan tässä lehdessä.

Suomen tieteellisen kirjastoseuran lehti Signum on perustettu vuonna 1968 ja se täyttää tänä vuonna 50 vuotta. Juhlavuoden kunniaksi lehden visuaalinen ilme uudistetaan Tiedekustantajien liiton apurahalla, joka on rahoitettu Kopioston keräämillä tekijänoikeuskorvauksilla. Uusi Signum ilmestyy syksyllä - palataan asiaan!

Johanna Lahikainen

\section{Lähteet}

Annukka Saariston haastattelu, tekijät Susanna Nykyri, Jussi Omaheimo, Irma Reijonen, Antti Virrankoski: https://youtu.be/J16JFHgd8qk

Juha Raition haastattelu, tekijät Susanna Nykyri, Jussi Omaheimo, Irma Reijonen, Antti Virrankoski: https://youtu.be/DpCQ5T3VuJM

Timo Turjan haastattelu, tekijät Susanna Nykyri, Jussi Omaheimo, Irma Reijonen, Antti Virrankoski: ei avoimessa verkossa.

Juhlaseminaari:

http://www.stks.fi/news/2158 